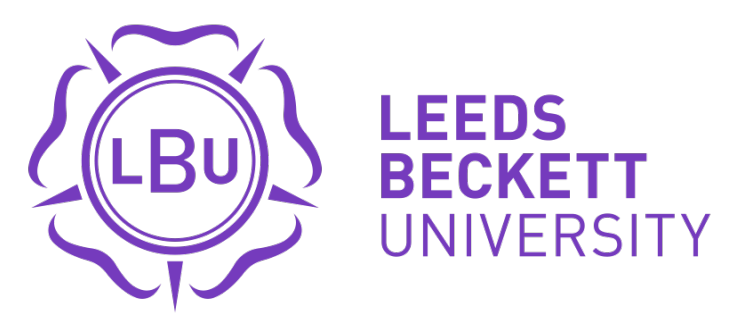

Citation:

Horwood, K (2019) The Development of Green Infrastructure Policy in the North West Region of the UK 2005-2010. Planning Practice and Research. ISSN 0269-7459 DOI: https://doi.org/10.1080/02697459.2019.1704538

Link to Leeds Beckett Repository record:

https://eprints.leedsbeckett.ac.uk/id/eprint/6438/

Document Version:

Article (Accepted Version)

This is an Accepted Manuscript of an article published by Taylor \& Francis in Planning Practice \& Research on 29 December 2019, available online: http://www.tandfonline.com/10.1080/02697459.2019.1704538

The aim of the Leeds Beckett Repository is to provide open access to our research, as required by funder policies and permitted by publishers and copyright law.

The Leeds Beckett repository holds a wide range of publications, each of which has been checked for copyright and the relevant embargo period has been applied by the Research Services team.

We operate on a standard take-down policy. If you are the author or publisher of an output and you would like it removed from the repository, please contact us and we will investigate on a case-by-case basis.

Each thesis in the repository has been cleared where necessary by the author for third party copyright. If you would like a thesis to be removed from the repository or believe there is an issue with copyright, please contact us on openaccess@leedsbeckett.ac.uk and we will investigate on a case-by-case basis. 


\title{
The development of Green Infrastructure policy in the North West
}

\section{region of the UK 2005-2010}

DR KAREN HORWOOD

\begin{abstract}
This article examines the development of green infrastructure policy-making in the North West region of the UK 2005-2010, through the articulation of three phases. Drawing on a conceptualisation of discourse coalitions, it is argued that this instance of the green infrastructure policy-making process became a way of bringing together various stakeholders around a shared goal. The activities that took place and how green infrastructure was conceptualized ensured that a range of policy interests was represented, and consequently, a stable discourse coalition was formed around economic priorities.
\end{abstract}

Key words: Green infrastructure; discourse coalition; interpretive policy analysis Dr Karen Horwood, The Leeds Planning School, School of Built Environment and Engineering, Leeds Beckett University, The Northern Terrace, City Campus, Leeds, LS2 8AG. Email: k.horwood@leedsbeckett.ac.uk 


\section{Introduction}

This article examines a particular instance of the development of green infrastructure policy in the UK through the case study of the North West region from 2005 up until the change in government in 2010. Green infrastructure saw an increasing interest within the UK during this time frame (Mell 2017), from conceptual discussions (Benedict and McMahon, 2002) through to incorporation into the policy-making environment. By the end of this period, green infrastructure's position within the spatial planning policy-making within the UK had solidified (Thomas and Littlewood, 2010; Horwood, 2011).

Whilst there has been a burgeoning of green infrastructure research in the last decades, the focus has been on its application within a variety of policy areas such as climate change (Gill et al, 2007; Demuzere et al, 2014), sustainability (Ahern, 2007; Sandstrom, 2002; Walmsley, 2006), health (Dapolito Dunn, 2010; Coutts and Hann, 2015; Mell, 2007), ecosystems (Tzoulas et al, 2007; Lennon and Scott, 2014) and water management (Dapolito Dunn and Stoner, 2007; Ellis, 2013). There has been less of an engagement with the policy-making process itself.

However, green infrastructure is a contested concept (Wright, 2011) with its meanings reflecting the policy context into which it is incorporated (Thomas and Littlewood, 2010; Horwood, 2011, Lennon, 2015). Consequently, discussions of green infrastructure need to take place within the particular context of its development. Whilst attempts have been made elsewhere to develop of chronology of green infrastructure's development (Mell, 2017) this paper draws on interpretive approaches to policy analysis, resulting in a starting point of complexity in any attempts to track the development of green infrastructure; policy-making is not a simple linear process rather its complex networks and relationships instead lead to messy and fluid boundaries.

This article draws on a particular instance of green infrastructure policy development to tell this complex story. Drawing on policy documents and interview data the development of 
green infrastructure policy in the North West region of the UK is examined to critically explain the form that policy took and the context that led to this particular framing.

\section{Interpretive policy analysis and discourse coalitions}

In the past policy development was seen as a process of rational, hierarchical decisionmaking, focused on achieving the best outcome through the appropriate use of neutral data (Fischer and Gottweis, 2012; Hajer and Versteeg, 2008). Consequently, policy analysis sought to assess the outcomes of policy interventions, to ascertain whether they were successful at achieving their stated aims (Fischer and Gottweis, 2012; Schwartz-Shea and Yanow, 2012). However, this way of seeing the policy-making process began to be problematized and the belief that policy-making was merely a value-free, technical project began to be questioned (Forester, 1989; Fischer and Forester, 1993; Flyvbjerg, 1998). A focus on the uncontrollability and complexity of the issues facing the world, and the resultant lack of simple solutions, instigated a change in perception of the policy-making to a far messier and difficult process (Fischer and Gottweis, 2012).

These shifts in the ways of seeing policy-making led to a turn away from the scientific positivist method, and towards a focus on meaning-making in the policy-making process (Healey, 2007; Schwartz-Shea and Yanow, 2012; Wagenaar, 2011). Policy-making became seen as a process through which issues are framed in particular ways, by the construction of narratives by those involved (Fischer and Gottweis, 2012; Yanow, 2000; Wagenaar, 2011). Analysis needs to focus on what policy means and how it came to mean it (Yanow, 2000). This process involves struggles over meaning and how policy issues and solutions are framed (Fischer and Gottweis, 2012; Yanow, 2000). Consequently, the focus on policy analysis becomes the development of an explanation of why one policy was developed rather than another and how it came to dominate (Howarth and Griggs, 2012).

Discourse coalitions can explain the emergence of policy priorities and the establishment of hegemonic policy discourses (Griggs, 2005). The discourse coalition can unite through a 
policy concept which does not have a settled meaning, through bringing together multiple interests and combining previously disparate storylines. For example, Torfing (2005) examines the breakdown of consensus on Danish unemployment welfare policy following a sustained period of economic crisis. This led to a moment in which a new 'activation' discourse, where unemployed people needed to participate in an active process to return to work, took hold. Torfing (2005) highlights that the notion of activation was ambiguous and that this was crucial for its sedimentation. The ambiguity enabled multiple interpretations which helped unify network actors who could justify their participation within their policy frame, 'The actors were all singing different songs addressed to their particular constituencies, but the chorus was the same: structural unemployment is the problem and activation is the solution.' (Torfing, 2005, p. 125).

Discourse coalitions can be held together through the logics of both equivalence and difference (Glynos and Howarth, 2007). Firstly, hitherto unrelated policy demands can be discursively constructed as equivalent to one another, where the achievement of one policy demand becomes intrinsically linked to the achievement of another, thus connecting the interests of previously disparate policy actors. Secondly, policy demands outside the coalition can be discursively set as different to the demands of those within. For example, Howarth and Griggs (2007) describe the role of the Freedom to Fly campaign in bringing together disparate supporters of airport expansion to speak with a united voice. This required unifying competing and disparate groups such as airlines, producers and consumers of airport services, and owners and workers. Through a focus on a support for growth interests were framed as equivalent, in marked contrast to those opposing growth (Howarth and Griggs, 2007). This process of establishing what is inside and outside works to shore up the coalition through the establishment of both common interests within and a common enemy outside.

In this article, this discourse coalition theory is applied to the example of green infrastructure policy formation in the North West region of the UK. In the coming sections, I will examine 
how the three different phases of the development of green infrastructure policy worked to establish a green infrastructure discourse coalition focused on the development of both policy and practice.

\section{Research strategy}

To examine the development of green infrastructure policy, it is necessary to both examine the policy itself, and also the processes that bring the policy into being. Consequently, this research project comprised of an analysis of 41 documents relating to green infrastructure in the North West and 34 interviews with green infrastructure policy-makers and practitioners. Whilst the policy documents demonstrate what was produced, the interviews enable an understanding of the processes of policy formation, and how and why the policy was brought into being in the ways it was.

Key green infrastructure documents were identified through the Green Infrastructure North West's website, with the corpus then expanded through following the 'intertextual trail' (Schwarz-Shea \& Yanow, 2012, p.70), by following up on all references made within each document and repeating this for those documents until the process is exhausted resulting in a comprehensive archive of sources.

In addition, 34 interviews were carried out with people who were involved in the development of green infrastructure policy, in their capacity as authors of green infrastructure policy reports in the North West region and Greater Manchester sub-region and as members of the green infrastructure steering groups formed both regionally and sub-regionally to develop green infrastructure policy, alongside organisations and individuals who were part of formal and informal green infrastructure networks. Identification of interviewees had several strands: firstly, membership of steering groups regional and sub-regional scales; secondly key actors in organisations responsible for writing documents identified above; thirdly attendees at green infrastructure policy dissemination events; and finally a snowballing 
approach was used to identify further interviewees. Through this, I was able to access key actors from all relevant organisations across the scales, except two Local Authorities.

The document and interview data were analysed using an immersive, iterative approach framed within interpretive analysis (Flyvbjerg, 2001; Schwartz-Shea and Yanow, 2012; Wagenaar, 2011), with a focus on critically explaining why the policy-making process took the particular form it did, and why this was successful in bringing together policy-makers. The material is structured in three sections (figure 1), each focusing on a different phase of this policy development process: Developing and Conceptualising, Consolidating and Implementing \& Extending.

[Figure 1]

\section{Phase 1: Developing and Conceptualising}

The story of green infrastructure in the North West begins with impetus from two organisations, Natural England in the North West (NEnNW) and the Community Forests (CF). Natural England was established through the Natural Environment and Rural Communities Act 2006, as an amalgamation of the Countryside Agency, English Nature and the Rural Development Service (Natural Environment and Rural Communities Act 2006). Part of its role became the promotion of green infrastructure with dedicated personnel whose task it was to provide support and expertise. In the North West this consisted of one officer who acted as an advocate.

The Community Forests were established in 1990 as a community resource with functions such as regeneration, community involvement and environmental improvement (Blackman \& Thackery, 2007). Within the North West, two were established: Red Rose Forest close to Manchester and the Mersey Forest close to Liverpool. In 2005 a shift in funding led to a need for Community Forests to ensure their activities aligned with priorities at the regional or local scale to make the case for continued funding (Vaughan, 2006). Within the North West this focused on alignment with North West Development Agency (NWDA), established in 
1998 with responsibility for the regeneration and economic development of the north-west region (Regional Development Agencies Act 1998).

NEnNW were involved in working with Community Forests to lobby the NWDA for financial support focussing on using the concept of green infrastructure to sell the Community Forests. Green Infrastructure was seen as a way of packaging the Community Forests to appeal to the priorities of the RDA:

It [green infrastructure] actually came originally as an agenda for Community Forests succession [...] that [Natural England funding for Community Forests] came to an end in 2005. We'd already sussed that Community Forests as a concept was a hard sell but there was still a hell of a lot of work to do. What the [Community] Forests were actually doing was environmentally-led regeneration. So we recast it as Green Infrastructure... (NEnNW1)

Whilst focused on the economy, the NWDA had a history of green-space related activity to deliver its economic objectives, for example the Newlands project supported by the NWDA from 2003 invested £32 million over 13 years to convert 347 hectares of former brownfield sites into woodlands (Newlands, undated). This connection between green-space and economic development was not one always made by other RDAs. It was framed with some pride by the NWDA interviewee as a break from the usual way that RDAs responded to demands and a new approach they pioneered:

And I think at the time that was quite a bold statement to make in terms of being an economic development agency. To recognise the notion that there was value in creating non hard end development (NWDA1)

It was felt by those working on Community Forests' succession planning that the NWDA represented a fertile source of funding where the activities of the former could be framed as contributing to the economic focused targets of the NWDA:

...we looked more at the economic and regeneration policy, trying to work with our RDA, and work on that kind of agenda, looking at the economic objectives of Green Infrastructure [....] Now over time it becomes more complicated, so we started with a simple plan really, is let's 
convince these people that what we're doing relates to what they're doing, so they'll give the sub-regional partnerships lots of cash to go away with and do Green Infrastructure and we can all sit back happy. (NEnNW1)

This more instrumental reason for promoting green infrastructure is key to understanding how the conceptualisation of green infrastructure developed. However, it is important to recognize that this pragmatic approach does not account for all involvement in the development of green infrastructure in the region. Nor is it the only reason for the enthusiasm from advocates within Natural England and the Community Forests. Green infrastructure was also seen as a way of delivering the wider aims and objectives of both these organisations and consequently, there is a vastly more complex story to tell.

Alongside Community Forests and Natural England, there were also professionals from other fields who came together to support this initiative and who provided the impetus for its development. These people came from various policy-fields and backgrounds, with differing motivations for their engagement. Some had become interested in green infrastructure before its development in the region, others were attracted to the ways it was developing in the North West. This included specialists from sectors such as planning, transport and development; private consultants with a background and personal interest in green-space; and environmentalists involved with foci such as ecology, climate change, green streets and biodiversity. The regional green infrastructure coalition included stakeholders with differing priorities, motivations and levels of engagement.

The strategy adopted within the region was multi-faceted and entailed actions to embed green infrastructure within other influential policies, alongside moves to establish a greater understanding from relevant organisations and recognition of the potential for its development and use. The former consisted of relatively clear, deliberative actions which expedited green infrastructure through its inclusion in policies which were influential. However, the latter was a complex process which can be conceptualised as a discursive storyline that green infrastructure advocates across disciplines could coalesce around. 
These two elements were complementary: green infrastructure would not have entered policy without support from policy-makers, and its existence in policy resulted in greater awareness and engagement. However, these two dimensions to the strategy took different forms and will be addressed individually in this paper, firstly concentrating on the actionfocused process followed by a discussion of how the more complex process of garnering support operated.

\section{Embedding green infrastructure in regional policy}

Green Infrastructure advocates in the North West sought to ensure that green infrastructure was included in the appropriate regional strategic policies: the Regional Economic Strategy (RES) prepared by the Regional Development Agency, and the Regional Spatial Strategy (RSS) prepared by the Regional Assembly. The Office of the Deputy Prime Minister's PPS12 on Local Development Frameworks (LDFs) outlined the need for LDFs to be prepared 'taking into account urban and rural strategies, local and regional economic and housing strategies...' (Office of the Deputy Prime Minister, 2004, p. 4), and emphasised the link between the RSS and any local plans: 'The local development framework, together with the regional spatial strategy, provides the essential framework for planning the local authority's area.' (Office of the Deputy Prime Minister, 2004, p. 2). Consequently, embedding green infrastructure within the RES and RSS was described as giving impetus to its incorporation into policy.

The RES was the key policy produced by the North West Development Agency (NWDA). During the period focused on in this article, the NWDA was a key non-departmental public body with significant budget and influence. The Regional Development Agencies were funded centrally by government and administered European Union Regional Development Funds representing a significant budget. Whilst allocations varied, in $2009 £ 327 \mathrm{~m}$ was paid out in grants (NWRDA, 2009). Regional Economic Strategies were required to set out the priorities of the RDA and were used as a steer to the work they carried out (Regional 
Development Agencies Act 1998). Thus, inclusion of green infrastructure-related priorities within this policy was necessary to access significant resources from the NWDA. This was recognised in Advancing Delivery of Green Infrastructure in the North West report (TEP, 2005a) which included the recommended action to:

Work with NWDA to take forward the RES Review that incorporates principles of sustainable development and which provides leverage for investment in Green Infrastructure (TEP, 2005a, p. 13)

In 2006 the RES was published. Included within it was the following action linking the natural environment and the economy:

Develop the economic benefit of the region's natural environment through better alignment of environmental activities and economic gain. (North West Development Agency, 2006, p. 48)

This solidified the NWDA's commitment to including the natural environment, and consequently potentially green infrastructure, as a part of their remit.

Also created through the Regional Development Agencies Act 1998 were the Regional Assemblies (Regional Development Agencies Act 1998). In the North West, this body was comprised of mainly public sector bodies and had a significantly smaller budget than the NWDA. One of its tasks was to prepare the Regional Spatial Strategy (RSS). This strategy shaped planning policy and influenced local planning policy; local authorities were required to ensure that their planning strategy, their Local Development Framework, was in "general conformity' with the RSS (Office of the Deputy Prime Minister, 2004. p.38). As a result, incorporation of a policy within the RSS would have increased the likelihood of its inclusion in the LDF and thus its prioritisation at both regional and local scales.

The potential importance of this process for securing commitment to green infrastructure was recognized and consequently there was a desire amongst green infrastructure advocates to establish green infrastructure as a theme within the RSS. In 2008 the RSS for the North West of England was published. The objective of ensuring the inclusion of green infrastructure was achieved with the policy EM3, which stated: 
Plans, strategies, proposals and schemes should: identify, promote and deliver multi-purpose networks of greenspace, particularly where there is currently limited access to natural greenspace or where connectivity between these places is poor; and integrate Green Infrastructure provision within existing and new development, particularly within major development and regeneration schemes. (Government Office North West, 2008, p. 94)

The strategy to create a policy impetus for green infrastructure through its inclusion in the RSS and the RES was successful through the expression of a commitment to the natural environment in the RES and the more specific commitment to green infrastructure in the RSS. This was described as a "huge milestone [that provided] a hook for a lot of [green infrastructure] work to be done' (4NW1). When discussing green infrastructure with interviewees at the local authority level, the hook of green infrastructure's inclusion in these strategies was evident, with its inclusion in the RSS frequently given as the reason for engagement with green infrastructure.

However, ensuring green infrastructure was included regional strategies was not a simple task. Green infrastructure advocates needed to ensure that they were able to exert sufficient influence and make an appropriate case for green infrastructure's inclusion. There was a focus on raising the profile of green infrastructure with relevant organisations, providing spaces in which green infrastructure could be discussed and promoted, and building up infrastructure to support this. A part of this was the holding of events with presentations from a range of organisations, engaging with various aspects of green infrastructure, for example with a green infrastructure planning in the NW event in 2005 and in 2006 an event launching the consultation process for the development of a NW green infrastructure guide.

\section{Meaning-making and coalition building}

In conjunction with the more tangible dimension of the green infrastructure development strategy outlined above, there was also a more nebulous process of garnering support for green infrastructure. The planning policy process can be conceptualized in terms of soft governance where the boundaries become fuzzy, with policy-makers and practitioners 
coming together to collaborate in the development of strategies (Allmendinger and Haughton, 2009). Thus, planning policy-making becomes a communicative process where policy develops though shared meaning-making.

One of the key characteristics of this phase of green infrastructure policy-making was to build understandings of the concept of green infrastructure within the region. Documents produced and presentations made often included discussions of how green infrastructure could be defined, its benefits and the characteristics it had as a way of engaging with greenspace. Green infrastructure was not seen as a pre-determined concept, with a static and well-understood definition.

Some of the terminology can be quite, kind of, nebulous about what it is. (LA1)

It was instead a new and evolving concept, in need of explaining, and (re)shaping in a form appropriate to its particular situation:

Depends who you're trying to define it for, who the audience is. (LA1)

This process resulted in fluidity in the definitions of green infrastructure. Whilst there were boundaries and commonalities as to what was included when talking about green infrastructure, these are subject to change and re-negotiation. There was space for the emphasis to be shifted between different dimensions of green infrastructure, depending upon the particular audience, priorities or aims.

Planning can use this fluidity to provide a vision that can persuasively appeal to different actors (Gunder and Hillier, 2009). This dimension of green infrastructure was recognized by its advocates, described as a concept that could 'hang on different hooks' (NEnNW1). It could be invoked in differing ways to engage with differing policy interests, for example both environmentalists and those focused on economic objectives. Described by many interviewees as a 'circle of the converted' (LA1, NeNNW1, LA12, CFNW3) a group of people from fields such as regional development, regeneration, sustainability and nature conservation came together under the banner of green infrastructure. 
This coming together was fostered through the establishment of a green infrastructure unit in 2005, a think tank in 2006, and a forum in 2007. The unit was a formalisation of the Community Forests involvement in green infrastructure and gave support to '.. deliver and develop the concept of Green Infrastructure' (Red Rose Forest, 2011) with a role to '...circulate information and stimulate debate among local and regional stakeholders.' (Red Rose Forest, 2011). The green infrastructure think tank brought together those interested in steering the development of green infrastructure, its key advocates and experts. The forum was a largely ad hoc body providing opportunities to come together to discuss green infrastructure focusing on delivery. These fostered a coherent and united coalition of organisations united in promoting green infrastructure.

For this process to be attractive to different fields and sectors, there needed to be a motivation for them to become involved. This was developed and sustained through promotion of the benefits of involvement in green infrastructure, contrasted directly with the negative impacts of not taking part. The choice was set up as being part of the green infrastructure circle and having a 'seat at the table' (LA1) or remaining outside and voiceless. Interviewees described how previous approaches were characterized as lacking coherency. The number of agencies working on environmental and green-space was highlighted and framed as a barrier to the interest from funders. This multiplicity was presented to interviewees as resulting in a confusing picture where the policy demands are unclear. There were also claims of conflict resulting in a mixed and confusing message. Green infrastructure brought together these different elements under one policy banner and led to a clearer message to those outside of the sector. In addition, the sector was criticised for the overly technical nature of some of these voices. Interviewees reported that environmental policy-making was depicted as too complex and specialist to be understood by people outside of the field and thus off-putting. This technical or scientific expertise was framed as a barrier to the acceptance. Such voices were framed as in need of a more palatable policy narrative which green infrastructure claimed to deliver. Previous approaches were also 
framed as being unrealistic with a focus on environmentalism or conservation rather than recognition of a need to adapt to the economic agenda. Green infrastructure was presented therefore as the way these green interests could be included but framed in a way that gave them broader appeal.

Drawing on discourse theory, we can conceptualize these two elements of meaning-making and the building of a united coalition. The shift towards spatial planning resulted in a focus on the communicative process, where the act of planning was seen as one of mediating different interests and developing consensus through a discursive process. Within this frame, the process of green infrastructure meaning-making in the North West could be seen as a crucial part of the development of regional green infrastructure policy. Rather than simply being an incidental part of the process, it assumes importance in terms of the way it operates as a means of coalition building.

Schmidt (2012) uses the term coordinative discourse interaction to describe a situation where:

'...policy actors are engaged in creating, deliberating, arguing, bargaining, and reaching agreement on policies...' (Schmidt, 2012, p. 100)

To do this, different policy actors organize themselves into discursive communities to influence policies. Hajer $(1993 ; 1995)$ uses the term discourse coalition to describe this process. He defines a discourse coalition as '.... group of actors who share a social construct.' (1993, p. 45). He highlights that the way this is constructed is a significant part of the political process. Policy-makers develop storylines which ' ...suggest certain social positions and practices, and criticize alternative social arrangements.' (1993, p. 47). These storylines are used to drive policy development in a particular direction and draw people in. Those in the coalition may not agree on every aspect of the issue, they may disagree for example over whether social benefits or economic benefits are the priority. However, they come together in a way that enables them to drive forward a policy for mutual benefit (Schmidt, 2012). In this way, the discourse coalition only holds together in so far as there is 
a reason for each actor to be involved, illustrated by an interviewee from the Environment Agency:

It's one of these things that, over time, if various groups carry on talking, interesting though that is, the it'll probably be less relevant, and less of a priority to the Environment Agency [...] if all this just keeps rumbling on and never leads to positive action, then it becomes less and less important to the agency [...] So I think the next 12 months are critical, if it can't be seen to have a future then... or if it can't be seen to hold its own with everything else then it's time to choose a different champion. (EA2)

In conclusion, this first phase of the development of green infrastructure policy saw a focus on meaning-making which brought together a coalition of organizations around a shared interest of promoting green-space within an economic remit to secure investment. This position was shored up through the incorporation of green infrastructure into the RSS and RES. In the next phase, we will see attempts to consolidate this position by taking further the focus on green infrastructure's ability to deliver economic benefits.

\section{Phase 2: Consolidating}

In 2007 the 3-year Natural Economy North West (NEcNW) programme was established. This was a result of work by Natural Environment North West (NEnNW) and the North West Development Agency (NWDA), to continue momentum following green infrastructure's inclusion in the RES. The NEcNW programme was funded mainly by NEnNW and NWDA (along with a small amount of subsidy from the 'Enriching Nature' programme of the SITA Trust, an organisation which distributed landfill tax revenue). NEcNW was linked explicitly to the delivery of the RES as the delivery agency for Action 113 focused on the economic benefit of the natural environment (North West Development Agency, 2006). NEcNW was a 3-year programme of work focusing on research and advocacy (Ecotec, 2008).

A key difference in this current Consolidating phase from the work that went before is the explicit location of green infrastructure within an economic discourse. This process began in 
the Developing and Conceptualising phase however the NEcNW project set the course of green infrastructure in a direction focused on economic benefit. A representative of the NWDA describes the establishment of the NEcNW project thus:

Showing that the natural environment has a direct economic benefit was something we wanted to prove more than had been done in the past. (NWRDA1)

Outputs of the project included the publication of reports commissioned by the NEcNW steering group focused on three themes. Firstly, a focus on establishing and promoting the economic benefits of green infrastructure, an outcome of which was the development of 11 economic benefits. Secondly, a technocratic approach to measure and quantify green infrastructure through investigating the use of software or developing tests to demonstrate value. And thirdly, green infrastructure showing how it could facilitate grey infrastructure and economic regeneration developments in more sustainable ways.

\section{Economic benefits}

The work of Natural Economy North West focused on green infrastructure as an economically-driven approach with an emphasis on the connection to economic priorities in contrast to ecology. The reason for this focus is illustrated by a representative of the NWDA:

I would take the view [...] that we don't have an economy unless the environment's right. But most of the work that this organisation is driven by doesn't come from that starting point. [...]. So the job of that piece of work, and all the work we're doing on economic benefits and valuing things, is to try and convince people that they should be coming at it from that perspective. (NWDA1)

One of the earliest documents published by NEcNW, The Economic Benefits of Green Infrastructure (Ecotec, 2008a), sets out the 11 economic benefits of green infrastructure. These 11 benefits (figure 2) became the de facto listing used within the region.

[Figure 2] 
The framing of the benefits in this way is used to locate green infrastructure within economic priorities making it more appealing to economic-focused organisations. The provision of these benefits was to enable those working on green infrastructure-related activity to make the economic case when seeking funding for projects:

[We] have been pragmatic and realised that if we don't say something has an economic benefit then people aren't going to take much notice (CABE1)

The development of the 11 economic benefits is a shift from a broader listing of benefits (see figure 3). It is of note that a shift from a more generalist listing of green infrastructure's benefits towards the 11 economic benefits is not simply a matter of removing those benefits that are social or environmental in nature; functions that are clearly environmental or socially driven continue to be included, albeit now framed as having economic credentials. [FIGURE 3]

\section{Valuing green infrastructure}

The second strand of the work of NEcNW was to quantify, measure and provide an economic value of green infrastructure. This began through a study of the feasibility of using off the shelf software (Kingston et al, 2008) and continued with attempts to separate benefit and financial value of an investment using the 11 economic benefits (Ecotec, 2008a). Later a series of economic tests were proposed to quantify the economic value of a green infrastructure investment (Ecotec, 2008b), supplemented with links to data sets and case studies of their application (Ecotec and IBIS, 2009; TEP, Ecotec and IBIS, 2009). In summary, these five reports demonstrate a strategy to frame the green infrastructure approach as one able to measure, quantify and value.

\section{Green infrastructure as enabling sustainable development}

The third theme within these documents is the representation of green infrastructure as enabling sustainable development. Green infrastructure is presented as a way of greening 
grey infrastructure developments (IBIS, 2008) with case studies provided to demonstrate this (IBIS, 2009a; 2009b). This approach is described by those who had historically been more focused on environmental priorities as an inevitable reflection of the changes in the world, with perhaps a resigned pragmatism behind the acceptance of this approach:

World is going to change, and things are going to change, there are powerful forces who want economic development. So do we want it sustainably and supporting green infrastructure or not. If we want them to be supporting we need to talk the right language and to be accepting that there's going to be some change (CFNW4)

\section{Phase 3: Implementing and extending}

In the previous two phases, we have seen the development of a discourse coalition through a focus on meaning-making, followed by the shift of green infrastructure towards a focus on economic priorities.

During this Implementing and Extending phase, the drive towards finding a way of measuring the economic value of green infrastructure continued. Alongside this, we can see a strand of work that also employed a technocratic method through using scientific evidence to make the case for green infrastructure as a response to climate change. Both of these strategies drew on the evidence-based approach prominent at the time (Parsons, 2002; Sanderson, 2002; Wells, 2007) with a focus on the use of data, defined processes and measurement to prove the need for green infrastructure. In this section, I will consider each of these strategies in turn.

\section{Continuing the focus on valuation}

The process of linking green infrastructure to economic interests continued with a focus on the monetized valuation of green infrastructure through the GENECON project which sought to develop a toolkit to enable calculation of the value of green infrastructure in an intervention. This project was commissioned by a consortium of public sector organisations 
from across the country including the NWDA and nationally from Department for Environment, Food and Rural Affairs (DEFRA) and the Commission for Architecture and the Built Environment (CABE). The work was carried out by GENECON a private sector consultancy with a focus on providing public sector business cases for investment.

The aim of the project was to develop the work of NEcNW to associate monetary value to each of the 11 economic benefits to attract investment:

It's built on work done by NEcNW [...] and various other studies trying to bring, preferably, monetary value, or trying to identify monetary value in investing in green infrastructure. (GEN1)

This continued a trend identified previously where the economic development sector had been identified as a potential source of funding. The strategic green infrastructure move to evidence the connection of green infrastructure's functions to economic priorities was thus continued:

The driver for this is really about trying to get the public sector to invest. If you're a development agency there's only a few things you want to buy. [...] But by and large these projects need to be tailored to potential funders which means there's a limit to the projects you can put in there. [...] they need to be attractive to funders. (GEN1)

\section{Building the scientific, evidence base}

However, in the Developing and Extending phase there was an alternative trajectory. Alongside the statutory RES and RSS, regional bodies were also responsible for the production of policies addressing various issues affecting the region. Whilst these were policy areas ostensibly in addition to economic development, due to their location within regional economic policy the connection to such a focus remained. One such policy area was climate change, with action 24 of the RES that outlined a priority to produce a Climate Change Action Plan. This action was responded to with the publication of two action plans, firstly a Climate Change Action Plan in 2006 (North West Development Agency, 2006) followed by a refreshed version in 2010 (North West Development Agency, 2010). Both of 
these Action Plans contained actions relating to green infrastructure, with the Community Forests named as the delivery agent.

In response to Action 4.3 (North West Development Agency, 2006) the Community Forests were funded by the NWDA to run a project from April 2008 - March 2010 with the task of linking green infrastructure to climate change adaptation and mitigation strategies (Community Forests Northwest, 2008). This resulted in the production of two documents which promoted green infrastructure in responding to climate change priorities (Community Forests Northwest, 2008; North West Green Infrastructure Unit, 2009). The first highlighted the resolution of climate change risks through the provision of green infrastructure whilst enabling economic development (Community Forests Northwest, 2008). Whilst the second explained how green infrastructure could remove the barriers to growth that might be presented by climate change.

\section{Conclusions}

This paper contributes to our understanding of the process of green infrastructure policymaking. Green infrastructure has attracted attention in both academic policy-making circles as a way of conceptualising and approaching green space management and development. However, this engagement often starts with green infrastructure as a static and bounded concept. As we have seen through the evidence presented here, green infrastructure instead is used more fluidly to bring together disparate stakeholders and shift towards the priorities of those holding both policy-making and monetary power.

In the case-study focused on here this takes the form of a focus on economic priorities. green infrastructure becomes a means through which to draw together various actors with diverse interests in green space around a shared conceptualisation of green infrastructure providing economic benefits. This enables a policy focus and associated funding opportunities that appeal to stakeholder. However, this is not to suggest that this would be 
the focus of green infrastructure in all instances. Rather than the conceptual breadth and ambiguity enables a bringing together of interests.

However, the coexistence of social, economic and environmental priorities alongside one another should not be viewed unproblematically. Whilst non-economic priorities continued to be listed, such a framing leads to an evaluation based on economic criteria. Whilst the shift in focus may have appeared to some green infrastructure advocates as little more than a language change, such a direction could have material impacts for the development of green infrastructure. Green infrastructure's multifunctionality may suggest the triple bottom line of accounting favoured in sustainable development, where the social, economic and environmental are all represented. However, experience would suggest that this leads to a dominance of the economic (Gunder and Hillier, 2009; Lennon, 2015). Whilst during the preimplementation stage this potential conflict was readily resolved through shifts in emphasis, material outcomes may be harder to balance; when decisions are being about the role of green infrastructure in the development of sites there is a danger that this shift towards the economic may be to the material detriment of the social and environmental. 
Ahern, J. (2007) Green Infrastructure for Cities: The Spatial Dimension. In: Novotny, V. and Brown, P. (eds) Cities of the Future: Towards Integrated Sustainable Water and Landscape Management London, IWA Publishing. pp. 267-283

Allmendinger, P. \& Haughton, G. (2009) Commentary: Critical Reflections on Spatial Planning Environment and Planning A 41 pp. 2544-2549

Benedict, M.A. and McMahon, E.T. (2002) Green Infrastructure: Smart Conservation for the $21^{\text {st }}$ Century. Renewable Resources Journal 20 (3), pp.12 - 17

Blackman, D. \& Thackray, R. (2007) The Green Infrastructure of Sustainable Communities: England's Community Forests England's Community Forests

Community Forests Northwest (2008) Critical Climate Change Functions of Green Infrastructure for Sustainable Economic Development in the North West Community Forests North West

Coutts, C. and Hahn, M. (2015) Green Infrastructure, Ecosystem Services and Human Health Environmental Research and Public Health 12 (8) pp. 9768-9798

Cullingworth, B. and Nadin, V. (2006) Town and Country Planning in the UK $14^{\text {th }}$ edition Abingdon: Routledge

Dapolito Dunn, A. (2010) Siting Green Infrastructure: Legal and Policy Solutions to Alleviate Urban Poverty and Promote Healthy Communities. Boston College Environmental Affairs Law Review 37 (1) pp. 45-70

Dapolito Dunn, A. \& Stoner, N. (2007) Green Light for Green Infrastructure Washington D.C: Environmental Law Institute

Demuzere, M., Orru, K., Heidrich, O., Olazabal, E., Geneletti, D., Orru, H., Bhave, A.G., Mittal, N., Feliu, E., Faehnle, M. (2014) Mitigating and adapting to climate change: multifunctional and multi-scale assessment of green urban infrastructure Journal of Environmental Management pp. 107-115

Ecotec (2008a) The Economic Benefits of Green Infrastructure: The public and business case for investing in Green Infrastructure and a review of the underpinning evidence Kendal: Natural Economy North West

Ecotec (2008b) The Economic Benefits of Green Infrastructure: Developing key tests for evaluating the benefits of green infrastructure Kendal: Natural Economy North West

Ecotec and IBIS (2009) How to Deliver, Measure and Demonstrate the Economic Contribution of the Natural Environment at a Project Level: A guide for project managers (draft) Kendal: Natural Economy North West

Ellis, J.B., Sustainable surface water management and green infrastructure in UK urban catchment planning Journal of Environmental Planning and Management 56 (1) pp. 24-41

Fischer, F. and Forester, J (eds.) (1993) The Argumentative Turn in Policy Analysis and Planning Durham, NC: Duke University Press

Fischer, F. and Gottweis, H. (2012) Introduction in Fischer, F. and Gottweis, H. (eds.) (2012) The Argumentative Turn Revisited Durham: Duke University Press pp. 1-27

Flyvbjerg, B. (1998) Power and Rationality Chicago: University of Chicago Press 
Flyvbjerg, B. (2001) Making Social Science Matter: Why social inquiry fails and how it can succeed again Cambridge: Cambridge University Press

Forester, J. (1989) Planning in the Face of Power Los Angeles: University of California Press

Gill, S.E., Gill, S.E., Handley, J.F., Ennos, A.R., Pauleit, S. (2007) Adapting Cities for Climate Change: The Role of the Green Infrastructure Built Environment 33 (1) pp. 115-133

Glynos, J. and Howarth, D. (2007) Logics of Critical Explanation in Social and Political Theory Abingdon: Routledge

Government Office North West (2008) The North West of England Plan: Regional Spatial Strategy to 2021 London: The Stationary Office

Greed, C. with Johnson, D. (2014) Planning in the UK Basingstoke: Palgrave Macmillan

Griggs, S. (2005) Problematizing the Mobilization of Hospital Directors in Howarth, D. and Torfing, J (2005) Discourse Theory in European Politics London: Palgrave Macmillan

Gunder, M. \& Hillier, J. (2009) Planning in Ten Words or Less: A Lacanian Entanglement with Spatial Planning Farnham: Ashgate

Hajer, M. (1993) Discourse Coalitions and the Institutionalisation of Practice: the Case of Acid Rain in Britain. In Fischer, F. \& Forester, J (eds.) The Argumentative Turn in Policy Analysis and Planning Durham: Duke University Press

Hajer, M. (1995) The Politics of Environmental Discourse: Ecological modernisation and the policy process Oxford: Oxford University Press

Hajer, M. (2005) Coalitions, Practices and Meaning in Environmental Politics: From Acid Rain to BSE in Howarth, D. and Torfing, J (2005) Discourse Theory in European Politics London: Palgrave Macmillan

Hajer, M. \& Versteeg, W. (2008) The Limits to Deliberative Governance Annual Meeting of the American Political Science Association Conference, Boston, August 28-31, 2008

Healey, P. (2007) Urban Complexity and Spatial Strategies: Towards a relational planning for our times London: Routledge

Horwood, K. (2011) Green infrastructure: reconciling urban green-space and regional economic development: lessons learnt from experience in England's North West Region Local Environment 16 (10) pp. 963-975

Howarth, D. and Griggs, S. (2007) Metaphor, Catachresis and Equivalence: The Rhetoric of Freedom to Fly in the Struggle over Aviation Policy in the United Kingdom. Policy and Society 25 (2) pp. 23-46

Howarth, D. and Griggs, S. (2012) Poststructuralist Policy Analysis: Discourse, Hegemony and Critical Explanation in Fischer, F. and Gottweis, H. (eds.) (2012) The Argumentative Turn Revisited Durham: Duke University Press pp. 305-342

IBIS (2008) Developing an Outline Strategy for Linking Green and Grey Infrastructure Kendal: Natural Economy North West

IBIS (2009a) Assessing the Potential for Green Infrastructure Development within Projects (Interim Report) Kendal: Natural Economy North West

IBIS (2009b) Assessing the Potential for Green Infrastructure Development within Projects (Final paper v3.1) Kendal: Natural Economy North West 
Kingston, R., Cahill, D., Handley, J., Tzoulas, K. and James, P. (2008) Toward a Green Infrastructure Valuation Model: assessing the potential for the CITYgreen GIS software for use as a tool for qualifying the economic benefits of green infrastructure in the UK Kendal: Natural Economy North West

Lennon, M (2015) Green infrastructure and planning policy: a critical assessment Local Environment 20 (8) pp. 957-980

Lennon, M. and Scott, M. (2014) Delivering ecosystems services via spatial planning: reviewing the possibilities and implications of a green infrastructure approach Town Planning Review 85 (5) pp. 563-587

Mell, I. (2007a) Green Infrastructure Planning: What are the costs for Health and Wellbeing? Journal of Environment, Culture, Economic and Social Sustainability 3 (5) pp. 117-124

Mell, I.C. (2017) Green infrastructure: reflections on past, present and future praxis Landscape Research 42 (2) pp. 135-145

Newlands (undated) Newlands Executive Briefing [Internet] Available from: $<$ http://www.newlandsproject.co.uk/> [Accessed 15 $5^{\text {th }}$ October 2019]

Natural Environment and Rural Communities Act 2006 (c.16) Available from:,http://www.legislation.gov.uk/ukpga/2006/16/contents> [Accessed $15^{\text {th }}$ Novemeber 2013]

North West Green Infrastructure Unit (2009) Green Infrastructure Solutions to Pinch Point Issues in North West England: how can green infrastructure enable sustainable development North West Green Infrastructure Unit

North West Green Infrastructure Unit (2010) Green Infrastructure: How and where it can help the Northwest mitigate and adapt to climate change? North West Green Infrastructure Unit

North West Development Agency (2006) Regional Economic Strategy Warrington: North West Development Agency

North West Development Agency (2009) Northwest Regional Development Agency Annual Report and Financial Statements: Year ended March 2009 London: HMSO

North West Development Agency (2010) Climate Change Action Plan Warrington: North West Development Agency

Office of the Deputy Prime Minister (2004) Planning Policy Statement 12: Local Development Framework (PPS12) London: HMSO

Parsons, W. (2002) From Muddling Through to Muddling Up - Evidence Based Policymaking and the Modernisation of British Government Public Policy and Administration 173 pp. $43-60$

Red Rose Forest (2011) Green Infrastructure [internet] Forest Available from: <http://www.redroseforest.co.uk/web/content/view/42/142/> [Accessed 15th November 2013]

Regional Development Agencies Act 1998 (c.45) [Internet] Available from: <http://www.legislation.gov.uk/ukpga/1998/45/contents> [Accessed 15 $5^{\text {th }}$ November 2013] Sanderson, I (2002) Evaluation, policy learning and evidence-based policy-making Public Administration 80 (1) pp. 1-22 
Sandström, U. (2002) Green Infrastructure Planning in Urban Sweden. Planning Practice and Research, 17(4), pp. 373-38

Schmidt, V. A. (2012) Discursive Institutionalism: Scope, Dynamics, and Philosophical Underpinnings in Fischer, F. and Gottweis, H. (eds.) The Argumentative Turn Revised: Public Policy as Communicative Practice Durham, NC: Duke University Press.

Schwartz-Shea, P. and Yanow, D. (2012) Interpretive Research Design Abingdon: Routledge

TEP, Ecotec and IBIS (2009) How to Deliver, Measure and Demonstrate the Economic Contribution of the Natural Environment at a Project Level: A guide for project managers Natural Economy North West

Thomas, K. \& Littlewood, S. (2010) From Green Belts to Green Infrastructure? The Evolution of a New Concept in the Emerging Soft Governance of Spatial Strategies Planning Practice and Research, 25 (2) pp. 203-222

Tzoulas, K., Korpela, K., Venn, S., Yli-Pelkonen, V., Kaźmierczak, A., Niemela, J. \& James, P. (2007) Promoting Ecosystem and Human Health in Urban Areas Using Green Infrastructure: A Literature Review. Landscape and Urban Planning 81 pp.167-178.

Vaughan, J. (2006) England's Community Forests England Executive Board, 4th July 2006, Agenda Item 10, Paper 34/06 [internet]. England's Community Forests Available from: $<$ http://www.forestry.gov.uk/pdf/eeb-jul06-paper-34.pdf/\$FILE/eeb-jul06-paper-34.pdf> [Accessed 27th August 2010]

Wagenaar, H. (2011) Meaning in Action: Interpretation and Dialogue in Policy Analysis New York: M.E. Sharpe

Walmsley, A. (2006) Greenways: multiplying and diversifying in the 21st century. Landscape and Urban Planning 76 pp. 252-290

Wells, P. (2007) New Labour and evidence based policy-making: 1997-2007 People, Place and Policy Online 11 pp. 22-29

Wright, H. (2011) Understanding green infrastructure: the development of a contested concept in England Local Environment 16 (10) pp. 1003-1019

Yanow, D. (2000) Conducting Interpretive Policy Analysis London: Sage 


\begin{tabular}{|l|l|l|l|}
\hline Phase & $\begin{array}{l}\text { Indicative } \\
\text { Chronology }\end{array}$ & Conceptualisation & Priorities \\
\hline $\begin{array}{l}\text { Developing and } \\
\text { Conceptualising }\end{array}$ & $2005-2008$ & $\begin{array}{l}\text { Conceptualisation } \\
\text { Meaning making } \\
\text { Promoting } \\
\text { Ensuring relevance }\end{array}$ & $\begin{array}{l}\text { Developing an understanding of } \\
\text { the concept within the region } \\
\text { Promoting to partners } \\
\text { Building a discourse coalition } \\
\text { Inclusion within the RSS and RES }\end{array}$ \\
\hline Consolidating & $2008-2010$ & $\begin{array}{l}\text { Building on the RSS/RES } \\
\text { inclusion through } \\
\text { developing appropriate } \\
\text { policies } \\
\text { Economic dimension }\end{array}$ & $\begin{array}{l}\text { Promoting the economic } \\
\text { dimension of GI } \\
\text { Developing a GI 'evidence base' } \\
\text { Linking GI to other regional } \\
\text { economic priorities } \\
\text { NEcNW project } \\
\text { Building GI at the sub-regional } \\
\text { scale }\end{array}$ \\
\hline $\begin{array}{l}\text { Implementing } \\
\text { and Extending }\end{array}$ & $2009-2010$ & $\begin{array}{l}\text { Widening of GI contexts, } \\
\text { e.g. climate change } \\
\text { adaptation and mitigation, } \\
\text { and conservation } \\
\text { Solidification of position } \\
\text { Moving towards delivery } \\
\text { LDF development }\end{array}$ & $\begin{array}{l}\text { Moving towards delivery of } \\
\text { physical Gl projects } \\
\text { LDF production } \\
\text { Connecting to climate change } \\
\text { policy }\end{array}$ \\
\hline
\end{tabular}

Figure 1 The phases of Gl policy development 


\begin{tabular}{|l|}
\hline 11 Economic Benefits (Ecotec, 2008a) \\
\hline Climate change adaptation and mitigation \\
\hline Flood alleviation and water management \\
\hline Quality of place \\
\hline Health and wellbeing \\
\hline Land and property values \\
\hline Economic growth and investment \\
\hline Labour productivity \\
\hline Tourism \\
\hline Recreation and leisure \\
\hline Land and biodiversity \\
\hline Products from the land \\
\hline
\end{tabular}

Figure 2 The 11 economic benefits of Gl

\begin{tabular}{|l|l|}
\hline 11 Economic Benefits (Ecotec, 2008a) & NW GI Think Tank (2008) \\
\hline Climate change adaptation and mitigation & Climate change adaptation and mitigation \\
\hline Flood alleviation and water management & Flood management \\
\hline Quality of place & Quality of place \\
\hline Health and wellbeing & $\begin{array}{l}\text { Physical health } \\
\text { Mental health and well-being }\end{array}$ \\
\hline Land and property values & Land and property value uplift \\
\hline Economic growth and investment & $\begin{array}{l}\text { Create a setting for economic } \\
\text { growth/regeneration }\end{array}$ \\
\hline Labour productivity & $\begin{array}{l}\text { Job creation and social enterprise } \\
\text { Skills and training }\end{array}$ \\
\hline Tourism & Natural tourism \\
\hline Recreation and leisure & $\begin{array}{l}\text { Sport } \\
\text { Culture }\end{array}$ \\
\hline Land and biodiversity & Biodiversity in situ \\
\hline Products from the land & Access to natural green-space \\
\hline & Community cohesion \\
\hline & Community safety \\
\hline & Environmental connectivity \\
\hline & Air and water quality \\
\hline & \\
\hline
\end{tabular}

Figure 3 The evolution of the benefits of $\mathrm{Gl}$ 